\title{
Description of brachial plexus of sloth (Bradypus variegatus) ${ }^{1}$
}

\author{
Silvia F. Alcântara ${ }^{2 *}$ (D), Marleyne J.A.L. Amorim², Priscilla V. Albuquerque ${ }^{2}$, \\ Emanuela P. Mesquita ${ }^{2}$ (D), Maria Eduarda L.C. Miranda ${ }^{2}$, Gilcifran P. Andrade ${ }^{2}$, \\ Nathalia E.O. Nascimento ${ }^{3}$ and Júlio C.S. Nascimento ${ }^{4}$
}

\begin{abstract}
Alcântara S.F., Amorim M.J.A.L, Albuquerque P.V., Mesquita E.P., Miranda M.E.L.C., Andrade G.P., Nascimento N.E.O. \& Nascimento J.C.S. 2020. Description of brachial plexus of sloth (Bradypus variegatus). Pesquisa Veterinária Brasileira 40(10):824-829. Departamento de Morfologia e Fisiologia Animal, Universidade Federal Rural de Pernambuco, Rua Dom Manoel de Medeiros s/n, Recife, PE 52171-900, Brazil. E-mail: alcantarabio35@gmail.com

The species Bradypus variegatus is known as the common sloth, an endemic mammal from neotropical regions, which has been suffering from devastating anthropogenic activities. Our study aimed to describe the brachial plexus of $B$. variegates, regarding the origin and distribution of nerves, through the sampling of 10 adult females. Analyses were carried out at the Anatomy Section, "Departamento de Morfologia e Fisiologia Animal", "Universidade Federal Rural de Pernambuco", under license no. 034/2015 of the Ethics Committee on the Use of Animals. The results determined that the brachial plexus of the common sloth starts from the fifth cervical spine segment until the second thoracic segment. This area contains the long and suprascapular thoracic nerves, which originate immediately from the medullary segment 5 and 6 , respectively, and from the pectoral, subscapular, axillary, radial, musculocutaneous, medial, forearm and ulnar medial cutaneous nerves, arising from a trunk comprised of cervical spine nerves (C) 7, C8, C9, and thoracic (T) 1 and T2. Regarding other wild and domestic animals, different suggestions were observed about the origin of the plexus in B. variegatus, however, the constituent nerves and their innervation areas did not demonstrate any discrepancies.
\end{abstract}

INDEX TERMS: Brachial plexus, sloth, Bradypus variegatus, Bradypodidae, thoracic members, spinal nerves, neuroanatomy, nervous system, morphology.

RESUMO.- [Descrição do plexo braquial do bicho-preguiça (Bradypus variegatus).] A espécie Bradypus variegatus é conhecida como preguiça-comum. Trata-se de um mamífero endêmico de regiões neotropicais que vem sofrendo com a ação antrópica devastadora. Esses Bradipodídeos possuem três dedos nos membros torácicos e pélvicos, são arborícolas consagrados e descem ao solo apenas para excretar e trocar de árvore. 0 estudo teve como objetivo descrever o plexo braquial de B. variegatus em relação à origem e distribuição

\footnotetext{
${ }^{1}$ Received on June 2, 2020.

Accepted for publication on July 12, 2020.

${ }^{2}$ Departamento de Morfologia e Fisiologia Animal, Universidade Federal Rural de Pernambuco (UFRPE), Rua Dom Manoel de Medeiros s/n, Recife, PE 52171-900, Brazil. *Corresponding author: alcantarabio35@gmail.com

${ }^{3}$ Departamento de Biologia, Universidade Federal Rural de Pernambuco (UFRPE), Rua Dom Manoel de Medeiros s/n, Recife, PE 52171-900, Brazil.

${ }^{4}$ Departamento de Zootecnia, Universidade Federal Rural de Pernambuco (UFRPE), Rua Dom Manoel de Medeiros s/n, Recife, PE 52171-900, Brazil.
}

dos nervos. Para tal, utilizou-se 10 fêmeas adultas. As análises foram realizadas no Pavilhão de Anatomia do Departamento de Morfologia e Fisiologia Animal da Universidade Federal Rural de Pernambuco, sob a licença no 034/2015 do Comitê de Ética no Uso de Animais. Os cadáveres foram obtidos após morte natural, fixados em formaldeído a $20 \%$, conservados em solução salina a $30 \%$ em tanques e dissecados para a visualização dos nervos destinados a inervar os membros e músculos torácicos. Uma vez feito, constatou-se que o plexo braquial da preguiça-comum se origina do quinto segmento espinal cervical, se estendendo até o segundo segmento torácico. Sendo formado pelos nervos torácico longo e supraescapular, de origem imediatamente do segmento medular 5 e 6 , respectivamente, e pelos nervos peitorais, subescapulares, axilar, radial, musculocutâneo, mediano, cutâneo medial do antebraço e ulnar, decorrentes de um tronco formado a partir de nervos espinais cervicais (C) 7, C8, C9, e torácicos (T) 1 e T2. Em comparação a outros animais silvestres e domésticos 
foram observadas diferentes disposições em relação à origem do plexo de $B$. variegatus, todavia, os nervos constituintes e suas áreas de inervação não apresentaram discrepâncias.

TERMOS DE INDEXAÇÃO: Plexo braquial, bicho-preguiça, Bradypus variegatus, Bradipodídeos, membro torácico, nervos espinais, neuroanatomia, sistema nervoso, morfologia.

\section{INTRODUCTION}

Sloths are placental mammals that have a herbivorous diet and low metabolism. They belong to the order Pilosa, superorder Xenarthra, which is considered as the most distinct group among the Eutheria, encompassing animals with distinct behaviours, habitats and morphologies (Fernandez \& Miranda 2007, Adami et al. 2013). Sloths are distributed across two genera due to the quantity of data available on their thoracic members, the genus Choloepus, two-toed and the genus Bradypus, three-toed. These animals are easily found in the neotropical regions. Bradypodidae are represented by four species: Bradypus variegatus, Bradypus tridactylus, Bradypus torquatus and Bradypus pygmaeus. The latter species is endemic to the Escudo de Veraguas Island, located in Panama, whereas the first species presents an extensive distribution and for this reason is known as the common sloth (Azarias 2005, Wilson \& Reeder 2005, Kaviar et al. 2012).

Characterised by their peculiar habitats, sloths live in the forest canopy, suspended by their claws and their bodies are covered by hairs which are covered by green algae which aids in their camouflage. They descend to the ground only to change tree or to defecate, as on the ground they become more susceptible to predators such as snakes and jaguars, due to their slow movements in this environment, which has contributed to the decrease in the number of individuals (Pauli et al. 2014). The introduction of exotic species and fragmentation of environments as a result of anthropic activities, culminate in their increased risk of extinction (Cullen Júnior et al. 2001). The genus Bradypus, has especially suffered from these impacts and according to the International Union for Conservation of Nature (IUCN 2019), some species are threatened such as $B$. torquartus which is classified as vulnerable and B. pygmaeus which is classified as critically endangered.

In terms of anatomical characteristics, sloths present differences in the number of cervical vertebrae, with Choloepus hoffmanni having five to six vertebra, Choloepus didactylus having six to seven, and B. variegatus having between six and nine vertebrae. This characteristic allows for these animals to rotate their heads up to 270 degrees, facilitating the search for food and better identification of potential predators. This skeletal variation has been associated with the number of spinal segments. However, between seven and eight cervical vertebrae have been found in domestic mammals (Hautier et al. 2010, Cruz et al. 2013).

It is already known that each pair of cervical spinal nerves enter through the intervertebral foramina above each corresponding vertebra, however the eighth pair of nerves pass below the seventh cervical vertebra (Getty et al. 1986, Adami et al. 2013). The ventral and dorsal roots are inserted into the intervertebral foramen and join together to form the brachial and lumbosacral plexuses (Dyce et al. 2010). Considering that this is a fragile region of the peripheral nervous system, with regard to trauma exposure, a lesion in the brachial plexus can cause serious damage, such as the paralysis of thoracic members, decreasing an individual's quality of life and impairing, principally, the locomotion of tree species (Nowak 1999, Pereira 2015). As this is an area of anatomical relationships with the mobile structures of the neck and shoulders, tractions can occur, resulting in lesions or even penetrating injuries (Flores 2006).

During the evolutionary process there was an ascension in the cranial direction of the spinal nerve trunks which contributed to the formation of the brachial plexus, where the fourth spinal nerve was reached in monkeys (Parada et al. 1989). Just as with these primates, it is expected that there will be a pathway coming off the brachial plexus trunk in the first cervical vertebrae in sloths, in a cranial direction, since monkeys and sloths are both tree-living animals, inhabiting similar habitats. In this context, we aim to describe the anatomy of this plexus in B. variegatus indicating the origin and distribution of constituent nerves, with the aim of providing clinical medical data for this species.

\section{MATERIALS AND METHODS}

In order to carry out this research, the project was approved under the license no. 034/2015 from the Ethics committee on the Use of Animals at the "Universidade Federal Rural de Pernambuco" (UFRPE) and SISBIO no. 46665-3, for which 10 adult female individuals of the species Bradypus variegatus Schinz, 1825 (Mammalia: Pilosa) were used. The animals were donated post natural death by the "Centro de Triagem de Animais Silvestres", CETAS-Tangará. The animals were then sent to the collection of the Area of Anatomy of the "Departamento de Morfologia e Fisiologia Animal" (DFMA) of the UFRPE. The analyses performed were properly described and the photos documented with the aid of a Canon T6 camera and a schematic drawing was produced to facilitate the understanding of the results. The names of the structures were based on the determinations of the Nomina Anatomica Veterninaria in 2017.

The corpses were fixed by the cannulation of the common left carotid artery, using 20\% formaldehyde and conserved in 30\% saline solution in tanks. The dissection was performed through a medial sagittal ventral incision, from the larynx to the xiphoid process of the sternum bone and through transverse insertions with the formation of lateral windows. A medial incision was then made from the root of the thoracic limb to the wrist, with the opening of skin and musculature for the identification of the nerves that constitute the brachial plexus.

\section{RESULTS}

The brachial plexus of the common sloth did not demonstrate anatomical variation between study specimens. The specimens presented eight cervical vertebrae and seven pairs of spinal nerves forming the plexus, with the emergence of the first pair between the fourth and fifth cervical vertebrae and the last between the second and third thoracic vertebrae. The plexus in both antimeres was derived from the fifth to the ninth cervical medullary segment and from the first and second thoracic segments, corresponding to the cervical spinal nerves (C) 5, C6, C7, C8 and C9 and the thoracis spinal nerves (T) 1 and T2 (Fig.1).

As for the brachial plexus arrangement in Bradypus variegatus, it was found that the long thoracic nerve emerged from the fifth cervical spinal segment, responsible for innervating the lateral portion of the chest. The suprascapular nerve originated 
from the sixth segment and supplied the deep musculature of the lateral region of the scapula (Fig.1 and 2).

A pattern comprised of two trunks was observed in the study animals, a cranial trunk originating from the junction of the convergence of the $\mathrm{C} 7$ and $\mathrm{C} 8$ nerves with the $\mathrm{C} 9$ nerve. The nerve originating from $\mathrm{C} 7$ and $\mathrm{C} 8$ emitted subscapular pathways, responsible for innervating the medial scapular muscles. The other trunk was comprised of T1 and T2 with the contribution of T3. The trunks, cranial and caudal, were joined together in a common trunk, from which two fascicles appeared, the ventral and dorsal, and from these came the innervation of the chest muscles and limbs (Fig.1 and 2).
From the common trunk came two pectoral nerves which innervated the pectoral muscles. The axillary nerve originated from the dorsal fascicle and ran through the medial scapular muscles, the thoracodorsal nerve (which innervated the dorsal portion of the chest and the radial nerve), extending in the direction of the deep lateral region of the arm. From the ventral fascicle came the medial cutaneous nerves of the forearm, the ulnar nerve, the median and musculo cutaneous nerves, the last two originated from a single nerve that suffered a bifurcation. The medial cutaneous nerves of the forearm, ulnar nerve and median nerve were distributed up to the forearm (Fig.2).
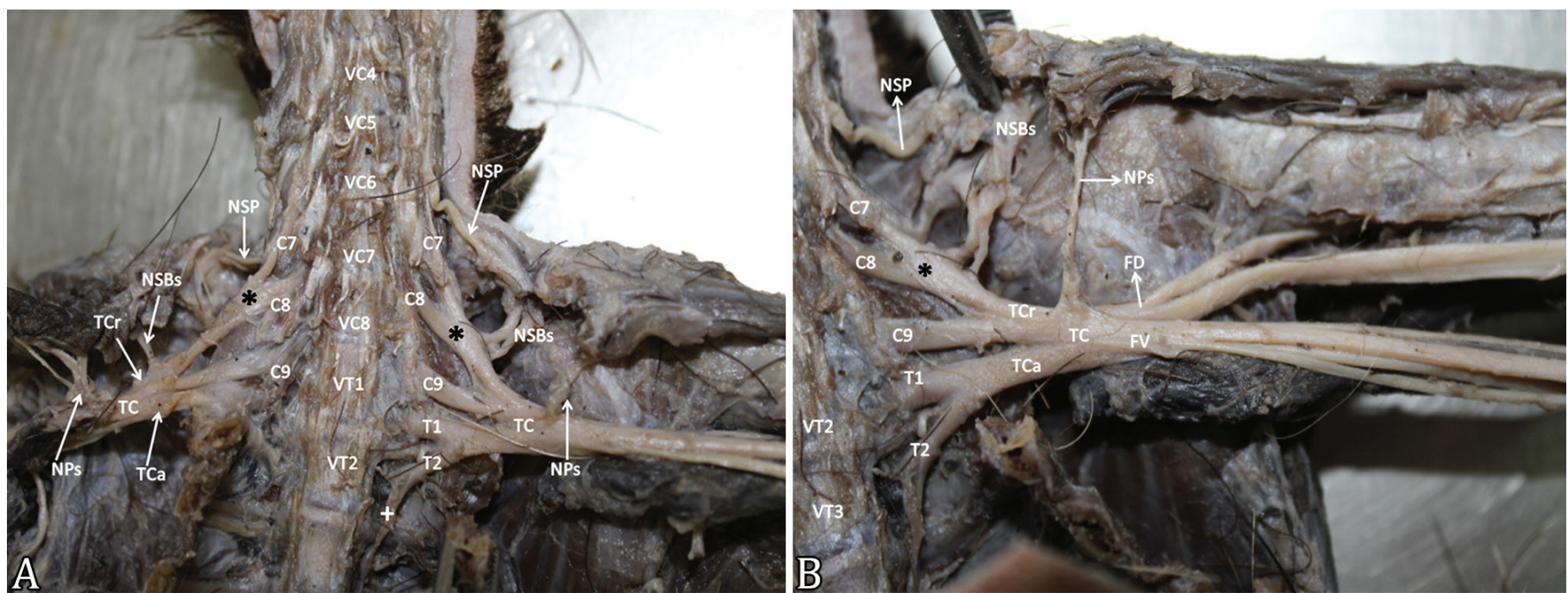

Fig.1. Photomacroscopy of the origin of the brachial plexus of the adult sloth (Bradypus variegatus). (A) Identification of the positioning of the cranial (TCr) and caudal (TCa) trunks forming the common trunk (TC). (B) Origin of the ventral (FV) and dorsal (FD) fascicles. The cervical vertebrae (VC), thoracic vertebrae (VT), cervical spinal nerves (C), thoracic spinal nerves (T), the nerve formed by the joining of the seventh and eighth cervical spinal nerves $\left({ }^{*}\right)$, the suprascapular nerve (NSP), the subscapular nerves (NSBs), the pectoral nerves (NPs), the contribution of the third pair of thoracic spinal nerves to the second pair $(+)$.
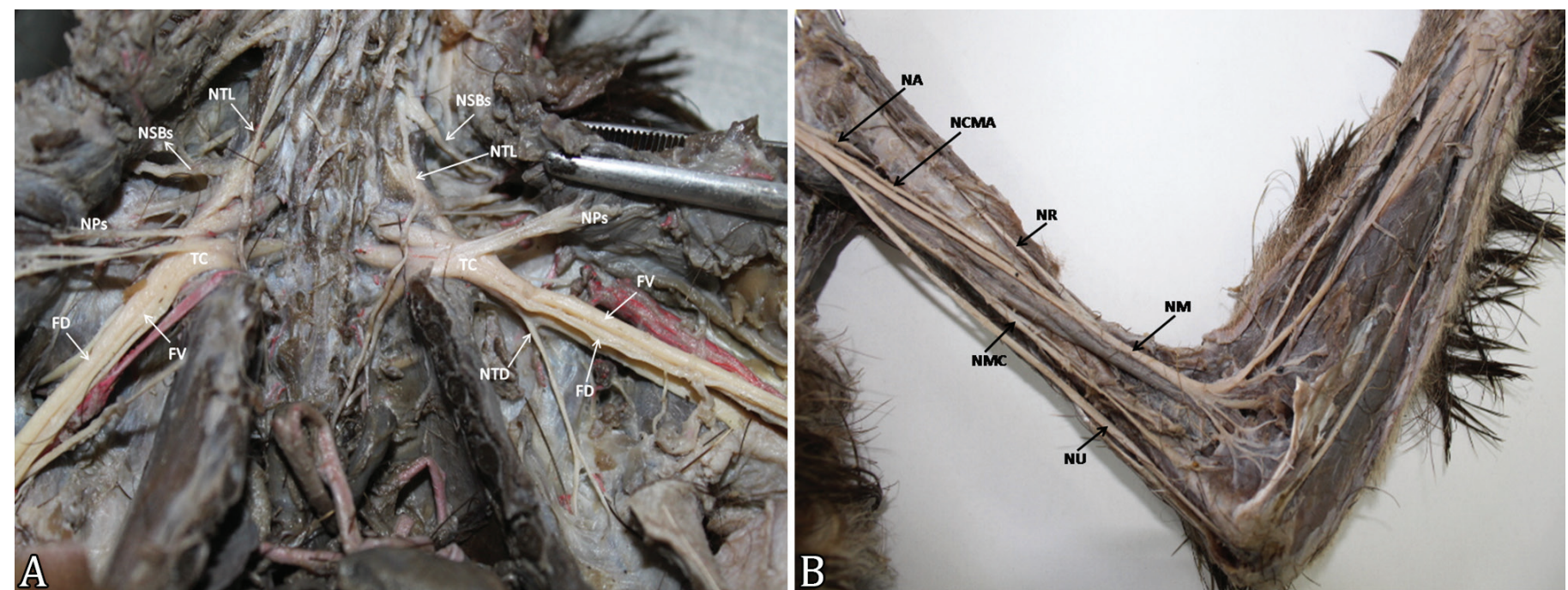

Fig.2. Photomacroscopy of the brachial plexus of the adult sloth (Bradypus variegatus). (A) Identification of the pathways near the common trunk (TC) and the dorsal fascicle (FD). (B) Identification of the distal pathways of the ventral (FV) and dorsal fascicles (FD). The subscapular nerves (NSBs), the long thoracic nerve (NTL), pectoral nerves (NPs), the thoracodorsal nerve (NTD), the axillary nerve (ND), the radial nerve (NR), the medial cutaneous nerve of the forearm (NCMA), the median nerve (NM), the musculocutaneous nerve (NMC) and the ulnar nerve (NU). 
The pattern observed for the distribution of the brachial plexus of the studied Bradypodidae can be seen schematically in Figure 3.

\section{DISCUSSION}

The brachial plexus of the common sloth originated from $\mathrm{C} 5$ to $\mathrm{T} 2$, with the contribution of T3. This information is different to that found in previous studies on other eutherians. In domestic animals, for example, the brachial plexus is more commonly formed by the C6 to T2 nerves (Ghoshal 1986). In studies by (Souza Junior et al. 2014) and (Vieira et al. 2013), they found that in Cerdocyon thous and Mazama gouazoubira the plexuses were comprised of the C6 to T1 nerves, whereas, for horses and cattle the plexuses were comprised of the $\mathrm{C} 6$ to $\mathrm{T} 2$ nerves. For wild mammals such as Hydrochoerus hydrochaeris, the plexus is formed by C4 to T1 nerves (Fioretto et al. 2003). Whereas, for Hystrix cristata, Agouti paca and Cebus apella, the brachial plexus was observed to be comprised of $\mathrm{C} 5$ to $\mathrm{T} 2$ nerves (Aydin 2003, Ribeiro et al. 2005, Scavone et al. 2008). C4 to T2 combinations were described for Tayassu tajacu (Moura et al. 2007), whereas Kawashima et al. (2007), Cruz \& Adimi (2010) and Santos et al. (2016) noted that for Leopardus geoffroyi, Pongo pygmaeus, Logothrix lagotricha, Callithrix jacchus and Callithrix penicillata the nerves extend from C5 to T1. According to (Moura et al. 2007), the variation in the origin of the brachial plexus may be related to embryological

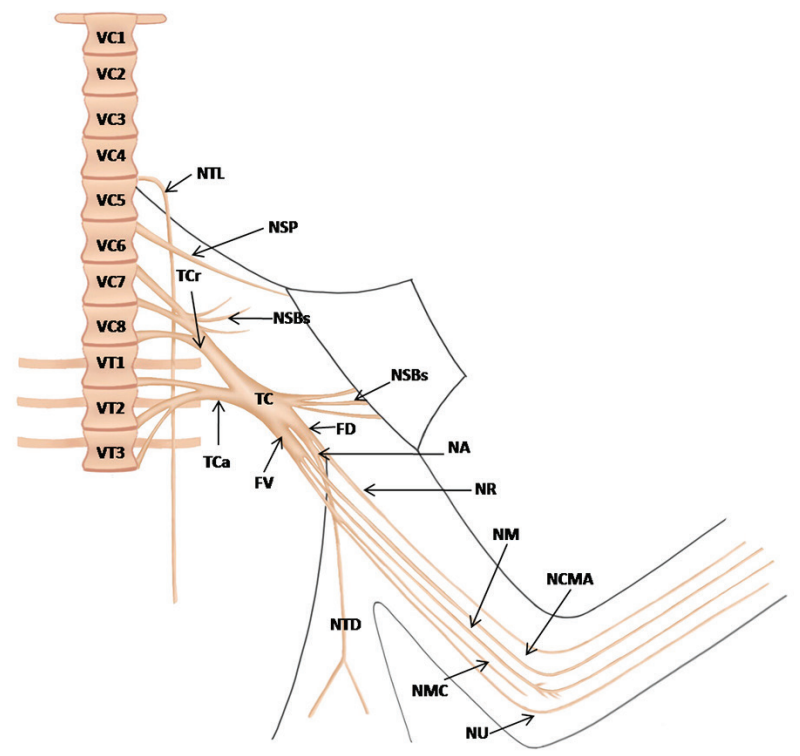

Fig.3. Schematic drawing of the brachial plexus of the adult sloth (Bradypus variegatus). Cervical vertebrae (VC), thoracic vertebrae (VT), cervical spinal nerves (C), thoracic spinal nerves, the nerve formed by the joining of the seventh and eighth cervical spinal nerves $\left({ }^{*}\right)$, the long thoracic nerve (NTL), the suprascapular nerve (NSP), subscapular nerve (NSBs), cranial (TCr), caudal (TCa) and common (TC) trunks, contribution of the third pair of thoracic spinal nerves to the second pair $(+)$, pectoral nerves (NPs), ventral (FV) and dorsal (FD) fascicles, thoracodorsal nerve (NTD), axillary nerve (ND), radial nerve (NR), medial cutaneous nerve of the forearm (NCMA), median nerve (NM), musculocutaneous nerve (NMC) and the ulnar nerve (NU). factors due to the position of limb bud development in relation to the neuro axis. According to (Hautier et al. 2010) and (Cruz et al. 2013), these alterations occur in relation to the variation in the number of cervical vertebrae. The formation of each nerve varies notably between species, due to the differences in their ability to use of thoracic limbs for defence, locomotion or searching for food (Dyce et al. 2010) (Table 1).

In regard to the Bradypodidae, previous literature notes that for the species Bradypus torquartus and Bradypus tridactylus, the brachial plexuses occurred from $\mathrm{C} 7$ to $\mathrm{T} 2$ nerves (Bielik 1837, Cruz et al. 2013), which is in concordance with the formation of nerve trunkes found in this study for B. variegatus. The sloths in this study presented plexuses formed by nerves that are distributed from a common trunk, formed by cranial and caudal pathways, which has also been described for B. torquartus, $H$. cristata, marsupials and lemurs (Miller 1934, Aydin 2003, Cruz et al. 2013, Ricci et al. 2013). However, this characteristic differs from that observed for other Xenarthrans, such as Tamandua tetradactyla, whose plexus is comprised of three trunks, as well as primates such as P. pygmaeus, L. lagotricha, C. jacchus and C. penicillata (Kawashima et al. 2007, Cruz \& Adimi 2010, Santos et al. 2016), and further demonstrates a difference from the description of Chinchilla lanigera which has four trunks and for pacas that do not present trunks (Gamba et al. 2007, Scavone et al. 2008, Ricci et al. 2013).

In terms of the pectoral nerves, in $B$. variegatus they originated from a common trunk, supplying the pectoral muscles, however, in B. torquartus and in H. cristata, these nerves emerged from the caudal trunk (Aydin 2003, Cruz et al. 2013). In dogs and cats, the pectoral nerves are divided into cranial and caudal nerves (Stüpp-De-Souza et al. 2010), which was not observed in $B$. variegatus. In this species, the suprascapular nerve came from the sixth cervical medullary segment and was inserted into the shoulder musculature, differing to $B$. torquartus, since the nerve presented a variation in terms of origin, emerging from the seventh cervical medullary segment or the cranial trunk (Cruz et al. 2013), which is similar to the primates L. lagothricha, C. jacchus and C. Penicillata (Cruz \& Adimi 2010, Santos et al. 2016).

Table1. The origin of nerves that comprise the brachial plexus of mammals

\begin{tabular}{lcc}
\hline \multicolumn{1}{c}{ Specie } & Origin & Reference \\
\hline Agouti paca & C5 to T2 & Scavone et al. (2008) \\
Bradypus trydactylus & C7 to T2 & Bielik (1937) \\
Bradypus torquartus & C7 to T2 & Cruz et al. (2013) \\
Bovines & C6 to T2 & Ricci et al. (2013) \\
Cerdocyon thous & C6 to T1 & Souza Junior et al. (2014) \\
Cebus apella & C5 to T2 & Ribeiro et al. (2005) \\
Equines & C6 to T2 & Ricci et al. (2013) \\
Hystrix cristana & C5 to T2 & Aydin (2003) \\
Hydrochoerus hydrochaeris & C4 to T1 & Fioretto et at. (2003) \\
Leopardus geoffroxi & C5 to T1 & Souza Junior et al. (2018) \\
Logothix logotricha & C5 to T1 & Cruz \& Adimi (2010) \\
Mazama gouazoubira & C6 to T1 & Vieira et al. (2013) \\
Pongo pygmaeus & C5 to T1 & Kawashima et al. (2007) \\
Tyassu tajuca & C4 to T2 & Moura et al. (2007)
\end{tabular}


The results indicate that four nerves originated from the ventral fascicle in $B$. variegatus: the medial cutaneous nerve of the forearm, the ulnar nerve, the median nerve and the musculocutaneous nerve. A common origin was observed for these last two nerves, however, they formed distinct nerves, which differs from other mammals where a separation does not occur, resulting in the formation of the median musculocutaneous nerve as with $B$. torquartus, the Capricornis crispus and $H$. hydrochaeris (Atoji et al. 1987, Fioretto et al. 2003, Cruz et al. 2013). In T. tetradactyla, H. cristata and Papio ursinus the median musculocutaneous nerve forks in the distal third of the arm and thereby forms the median and musculocutaneous nerves. However, in the anteater, the origin of the median musculocutaneous nerve occurs before the formation of the trunks, with T1 also contributing to this (Booth et al. 1997, Aydin 2003, Cruz et al. 2012). It was found that the medial cutaneous nerve of the forearm and the ulnar nerve, continued to the forearm, as was observed by (Cruz et al. 2013) for B. torquartus.

In the dorsal fascicle, the axillary nerve emerged from the caudal trunk, similar to B. torquartus and M. Gouazoubira (Cruz et al. 2013, Vieira et al. 2013). However, this differs to $H$. cristata, $P$ ursinus, T. Tetradactyla and L. lagotricha where the origin of the axillary nerve came from the cranial and middle trunks (Cruz \& Adimi 2010, Cruz et al. 2012). In regard to the radial nerve of the study specimens, it is comparable to those analysed for B. torquartus, $H$. Crisyaya, C. jacchus and $C$. penicillata with the nerve originating from the caudal trunk (Aydin 2003, Cruz et al. 2013, Santos et al. 2016). However, this characteristic is different from that described for C. lanigera, where the nerve was observed to come from the middle and caudal trunks (Gamba et al. 2007). In their studies on brachial plexuses in T. tetradactyla (Cruz et al. 2012), confirmed that the thoracodorsal nerve received contributions from all three trunks, cranial, middle and caudal, which differs from that found for the common sloth, where this nerve was found to originate exclusively from the caudal trunk.

\section{CONCLUSIONS}

The brachial plexus of Bradypus variegatus arose from the fifth cervical spinal segment, extending until the second thoracic segment, constituting the cranial and caudal trunks. Different anatomical dispositions were observed for the common sloth when compared to domestic and wild mammals in terms of constituent medullary segments of the brachial plexus. However, this is likely associated with the number of cervical vertebrae which varies between different species, since the nerves that comprise the plexus and the structures innervated by them, do not present discrepancies.

Changes in the origin of the plexus are due to variations in the insertion position of limb buds in relation to the neuro axis, since cervical vertebrae vary in terms of their quantity and shape, both for wild and domestic animals, which contributes to variation in the origin of nerves that comprise the brachial plexus.

Acknowledgements.- We thank the "Departamento de Morfologia e Fisiologia Animal" at the "Universidade Federal Rural de Pernambuco", Recife/PE, for the provision of the corpses and the space for the dissection of the specimens.

Conflict of interest statement.- The authors declare no conflict of interest.

\section{REFERENCES}

Adami M., Cruz G.A.M. \& Oliveira V.L. 2013. Características anatômicas do plexo braquial de bicho-preguiça-de-coleira (Bradypus torquatus Illiger, 1811). Biotemas 26(3):195-201. <https://dx.doi.org/10.5007/21757925.2013v26n3p195>

Atoji Y., Suzuki Y. \& Sugimura M. 1987. The brachial plexus of the Japanese serow (Capricornis crispus). Anatomischer Anzeiger 163(1):25-32. <PMid:3565786>

Aydin A. 2003. Brachial plexus of the porcupine (Hystrix cristata). Vet. Med. 48(10):301-304. <https://dx.doi.org/10.17221/5783-VETMED>

Azarias R.E.G.R. 2005. Morfologia dental da preguiça-de-coleira (Bradypus torquatus Illiger, 1858). Doctoral Dissertation in Sciences, Faculdade de Medicina Veterinária e Zootecnia, Universidade de São Paulo, São Paulo.

Bielik P. 1937. Constituição do Plexus Brachialis no Bradypus tridactylus. Arq. Anat. Antropol., Lisboa, 18:1-4.

Booth K.K., Baloyi F.M. \& Lukhele O.M. 1997. The brachial plexus in the Chacma baboon (Papio ursinus). J. Med. Primatol. 26(4):196-203. <https://dx.doi. org/10.1111/j.1600-0684.1997.tb00052.x><PMid:9416570>

Cruz G.A.M. \& Adami M. 2010. Anatomia do plexo braquial de macaco-barrigudo (Lagothrix lagothricha). Pesq. Vet. Bras. 30(10):881-886.<https://dx.doi. org/10.1590/S0100-736X2010001000012>

Cruz G.A.M., Adami M. \& Oliveira V.L. 2013. Características anatômicas do plexo braquial de bicho-preguiça-de-coleira (Bradypus torquatus Illiger, 1811). Biotemas 26(3):195-201. <https://dx.doi.org/10.5007/21757925.2013v26n3p195>

Cruz G.A.M., Adami M., Almeida A.E.F.S., Silva E.A.A.C., Faria M.M.M.D., Pinto M.G.F. \& Silva R.D.G. 2012. Características anatômicas do plexo braquial de tamanduá-mirim (Tamandua tetradactyla Linnaeus, 1758). Revta Bras. Saúde Prod. Anim. 13(3):712-719. <https://dx.doi.org/10.1590/S151999402012000300011>

Cullen Júnior L., Bodmer E.M. \& Valderes-Padua C. 2001. Ecological consequences of hunting in Atlantic forest patches, São Paulo, Brazil. Oryx 35(2):137-144. <https://dx.doi.org/10.1046/j.1365-3008.2001.00163.x>

Dyce K.M., Sack W.0. \& Wensing C.J.G. 2010. Tratado de Anatomia Veterinária. Guanabara Koogan, Brasil. 856p.

Fernandez F. \& Miranda F. 2007. Preguiças: conhecer para preservar. Nosso Clínico 10:44-48.

Fioretto E.T., Castro M.F.S., Guid W.L., Mainardi R., Souza R.R. \& Ribeiro A.A.C.M. 2003. Grossan atomic organization of thecapybara's (Hydrochaeris hydrochaeris) brachial plexus. Anat. Histol. Embryol. 32(3):169-174. <https://dx.doi.org/10.1046/j.1439-0264.2003.00453.x><PMid:12823103>

Flores P.L. 2006. Estudo epidemiológico das lesões praumáticas de plexo braquial em adultos. Arq. Neuro-Psiquiatria 64(1):88-94. <https://dx.doi. org/10.1590/S0004-282X2006000100018>

Gamba C.O., Castro T.F., Rickes E.N. \& Pereira M.A. 2007. Sistematização dos territórios nervosos do plexo braquial em chinchila (Chinchillalanigera). Braz. J. Vet. Res. Anim. Sci. 44(4):283-289. <https://dx.doi.org/10.11606/ issn.1678-4456.bjvras.2007.26629>

Getty R.S.S. \& Grossman J.D. 1986. Anatomia dos Animais Domésticos. Guanabara Koogan, Brasil. 2052p.

Ghoshal N.G. 1986. Nervos espinhais, p.1597-1600. In: Sisson S. \& Grossman J.D. (Eds), Anatomia dos Animais Domésticos. Guanabara Koogan, Brasil.

Hautier L., Weisbecker V., Sanchez-Villagra M.R., Goswami A. \& Asher R.J. 2010. Skeletal development in sloths and the evolution of mammalian vertebral patterning. Proc. Natl Acad. Sci. 107(44):18903-18908.<https:// dx.doi.org/10.1073/pnas.1010335107>

IUCN 2019. Red List of Threatened Species, 2019. International Union for Conservation Nature. Available at <http://www.iucnredlist.org> Accessed on Aug. 10, 2019. 
Kaviar S., Shockey J. \& Sundberg P. 2012. Observations on the endemic pygmy three-toed sloth, Bradypus pygmaeus of Isla Escudo de Veraguas, Panamá. Plos One 7(11):e49854. <https://dx.doi.org/10.1371/journal. pone.0049854><PMid:23185461>

Kawashima T., Yoshitomi S. \& Sasaki H. 2007. Nerve fibre tracing of branches to the coracobrachialis muscle in a bornean orangutan (Pongo pygmaeus pygmaeus). Anat. Histol. Embryol. 36(1):19-23. <https://dx.doi. org/10.1111/j.1439-0264.2006.00714.x>

Miller R.A. 1934. Comparative studies upon the morphology and distribution of the brachial plexus. Am. J. Anat. 54(1):143-175. <https://dx.doi. org/10.1002/aja.1000540106>

Moura C.E.B., Albuquerque J.F.G., Magalhães M.S., Silva N.B., Oliveira M.T. \& Papa P.C. 2007. Análise comparativa da origem do plexo braquial de catetos (Tayassu tajacu). Pesq. Vet. Bras. 27(9):357-362. <https://dx.doi. org/10.1590/S0100-736X2007000900001>

Nowak R.M. 1999. Walker's Mammals of the World. Johns Hopkins University Press, Baltimore. 1936p.

Parada H., Pineda U.H., Lagunas E.M. \& Vidal H.A. 1989. Variaciones anatômicas de las ramas raquídeas que constituyen los troncos de origen del plexo braquial. Anal. Anat. Normal 7:32-36.

Pauli J.N., Mendoza J.E., Steffan S.A., Carey C.C., Weimer P.J. \& Peery M.Z. 2014. A syndrome of mutualism reinforces the lifestyle of a sloth. Proc. R. Soc. B 281(1778):20133006. <https://dx.doi.org/10.1098/rspb.2013.3006> <PMid:24452028>

Pereira K.F. 2015. Antrozoologia e hematologia de preguiças comuns (Bradypus variegatus) de áreas urbanas. Master's Thesis in Animal Biology, Universidade Federal de Viçosa, Minas Gerais. 58p.

Ribeiro A.R., Prada I.L.S., Silva Z., Barros R.A.C. \& Silva D.C.O. 2005. Origem do plexo braquial do macaco (Cebus apella). 2005. Braz. J. Vet. Res. Anim.
Sci. 42(2):143-149. <https://dx.doi.org/10.11606/issn.1678-4456. bjvras.2005.26445>

Ricci G.D., Guazzelli Filho J., Silva J.R.CP., Matheus S.M.M. \& Filadelpho A.J. 2013. Plexo braquial de mamíferos e aves- Revisão de literatura. Revta Cient. Eletrôn. Med. Vet. 11(20):1-15.

Santos P.R.S., Silva M.H.R., Rodrigues A.R. \& Assis Neto A.C. 2016. Anatomic description of brachial plexus of Callithrix jacchus and Callithrix penicillata. Pesq. Vet. Bras. 36(9):901-904. <https://dx.doi.org/10.1590/s0100736x2016000900017>

Scavone A.R.F., Machado M.R.F., Guimarães G.C., Oliveira F.S. \& Gerbasi S.H.B. 2008. Análise da origem e distribuição dos nervos periféricos do plexo braquial da paca (Agouti paca, Linnaeus, 1766). Ciênc. Anim. Bras. 9(4):1046-1055.

Souza Junior P., Carvalho N.C., Mattos K. \& Santos A.L.Q. 2014. Origens e ramificações do plexo braquial no cachorro-do-mato Cerdocyon thous (Linnaeus, 1766). Pesq. Vet. Bras. 34(10):1011-1023. <http://dx.doi. org/10.1590/S0100-736X2014001000015>

Souza Junior P., Wronski J.G., Carvalho N.C. \& Abidu-Figueiredo M. 2018. Brachial plexus in the Leopardus geoffroyi. Ciênc. Anim. Bras. 19:e-50805. <http://dx.doi.org/10.1590/1809-6891v19e-51240>

Stüpp-De-Souza D.A., Castro T.F., Franceschi R.C., Silva Filho R.P. \& Pereira M.A.M. 2010. Formação do plexo braquial e sistematização dos territórios nervosos em membro torácico de lobos-marinhos (Arctocephalus australis). Braz. J. Vet. Res. Anim. Sci. 47(2):168-174.

Vieira L.G., Ribeiro P.R.Q., Lima M.O., Souza R.R., Valdes S.A.C. \& Santos A.L.Q. 2013. Origens e ramificações do plexo braquial do veado-catingueiro Mazama gouazoubira (Artiodactyla: Cervidae). Biotemas 26(1):137-146. <https://dx.doi.org/10.5007/2175-7925.2013v26n1p137>

Wilson D.E. \& Reeder D.M. 2005. Mammals Species of the World: a taxonomic and geographic reference. John Hopkins University Press, Baltimore. 2142p. 